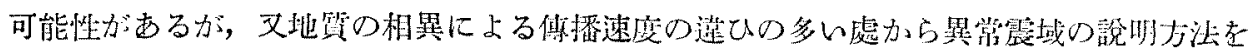
暗示与る样乲點为考入る事加出來る。

とにかく此の小諭から刋る處は上に述へた SeS の萑测から深發地震の深さを求めるこ

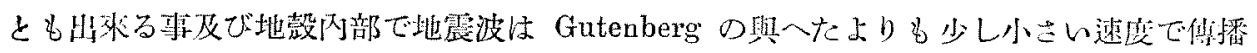
するのではするまいかと云的事である。

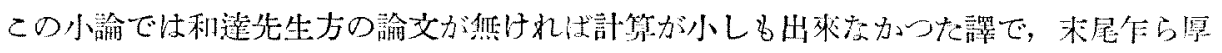

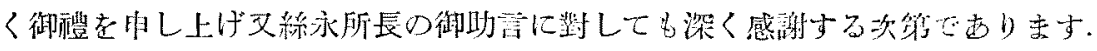

\title{
要，報 Notes
}

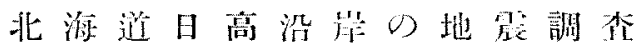

$$
\text { 野 村 新 太 毁 }
$$

On Eurthoukes of the Coast of Hidala, Hokkailo.

By S. Nomura.

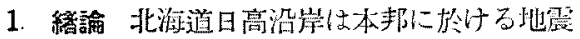
頻發地域の一であるが，特に近胙は其の活檕が盛 んで, 其の中にて1981 年2月17日浦河附近及 び 1939 年 11 月 36 日行冠川河口の雨者は多少

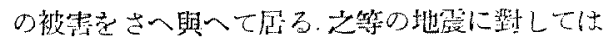

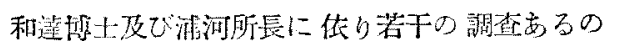

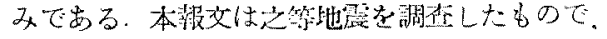

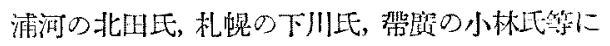
負心所衫引多い、此處に深謝の意を表子る。

調在された地震は 1931 年及び 1989 年の䨕河

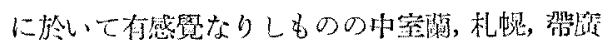

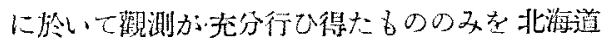

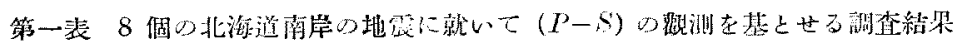

\begin{tabular}{|c|c|c|c|c|c|c|c|c|}
\hline & 1 & 2 & $\ddot{3}$ & 4 & 5 & 6 & 7 & 8 \\
\hline 發筑晴 & $\begin{array}{l}1931 \\
\text { II } 17 \mathrm{th} \\
4^{\mathrm{h}} 24^{\mathrm{ma}}\end{array}$ & $\begin{array}{l}1993 \\
\text { XI } 26 \text { th } \\
17^{\text {li }} 47^{\prime \prime \prime}\end{array}$ & $\begin{array}{l}1939 \\
\text { XI } 27 \text { th } \\
3^{\prime \prime} 49^{m}\end{array}$ & $\begin{array}{l}1938 \\
\text { XI } 27 \text { th } \\
4^{1} 3 L^{\prime \prime \prime}\end{array}$ & $\begin{array}{l}1992, \\
\text { XI } 28 \text { th }^{2} \\
4^{\text {l. }} 09^{\mathrm{m}}\end{array}$ & $\begin{array}{l}1932 \\
\text { XI } 30 \text { th } \\
\text { 7h } 08^{\mathrm{n}}\end{array}$ & $\begin{array}{l}1939, \\
\text { XII } 3 \mathrm{rd} \\
4^{4} 08^{\mathrm{n}}\end{array}$ & $\begin{array}{l}1982, \\
\text { III } 8 \text { th }^{2} \\
17^{\mathrm{b}} 51^{\mathrm{m}}\end{array}$ \\
\hline 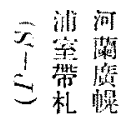 & $\begin{array}{r}27 \\
18.8 \\
11.4 \\
19.9\end{array}$ & $\begin{array}{l}75 \\
14.7 \\
145 \\
160\end{array}$ & $\begin{array}{l}7.5 \\
14.4 \\
145 \\
14.6\end{array}$ & $\begin{array}{l}8 \cdot 3 \\
14.4 \\
14.5 \\
15.8\end{array}$ & $\begin{array}{l}83 \\
136 \\
160 \\
161\end{array}$ & $\begin{array}{r}8.0^{\circ} \\
14.7 \\
145 \\
1.9\end{array}$ & $\begin{array}{r}80 \\
137 \\
145 \\
150\end{array}$ & $\begin{array}{r}7 * 3 \\
19 \% \\
110 \\
183\end{array}$ \\
\hline $\begin{array}{c}X \\
J \\
H I \\
K(\text { mean })\end{array}$ & $\begin{array}{l}26^{\mathrm{km}} \\
34 \\
29 \\
695\end{array}$ & $\begin{array}{l}42^{\mathrm{km}} \\
1 \\
43 \\
8 \cdot 11\end{array}$ & $\begin{array}{l}50^{\mathrm{km}} \\
15 \\
41 \\
805\end{array}$ & $\begin{array}{l}42^{k}+\cdots \\
0 \\
63 \\
891\end{array}$ & $\begin{array}{l}52^{\mathrm{km}} \\
-17 \\
52 \\
844\end{array}$ & $\begin{array}{l}48^{\mathrm{k} m} \\
13 \\
40 \\
8 \cdot 11\end{array}$ & $\begin{array}{l}50^{\mathrm{km}} \\
4 \\
4^{2} \\
819\end{array}$ & $\begin{array}{l}1^{\mathrm{kmi}} \\
29 \\
57 \\
843\end{array}$ \\
\hline 衻 可 & 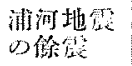 & 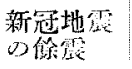 & 同左 & 同左 & 同左 & 同左 & 同左 & \\
\hline
\end{tabular}




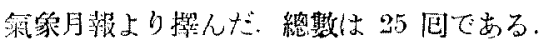

\section{2. 震央及露源の深さの決定}

震央の氿定は䘞期微動の比を用るる方法，時に 此の方法の用る蜼い埸合は適當な工夫に恢つた。

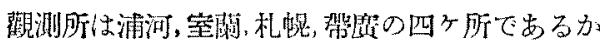

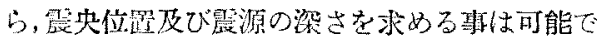

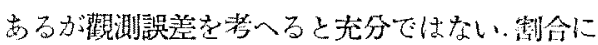

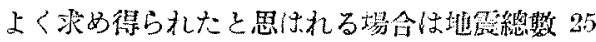

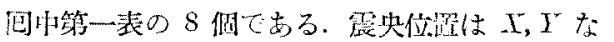

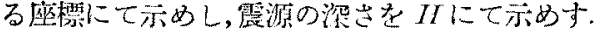

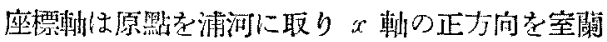
老通瀜才る方向， $y$ 軘は之と淔角に正方向を北 侧に取つた. 8 㑑の地震に就いては第一袁に示め ナ祖き結果方求められた。

筙一裴にて見られる扐く， $K$ の值は其の平均 としてれそ 81 程度分此の地域に於いては適當 らしい，故に残飭の地震に就いては $K$ の值 81

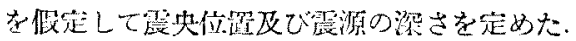

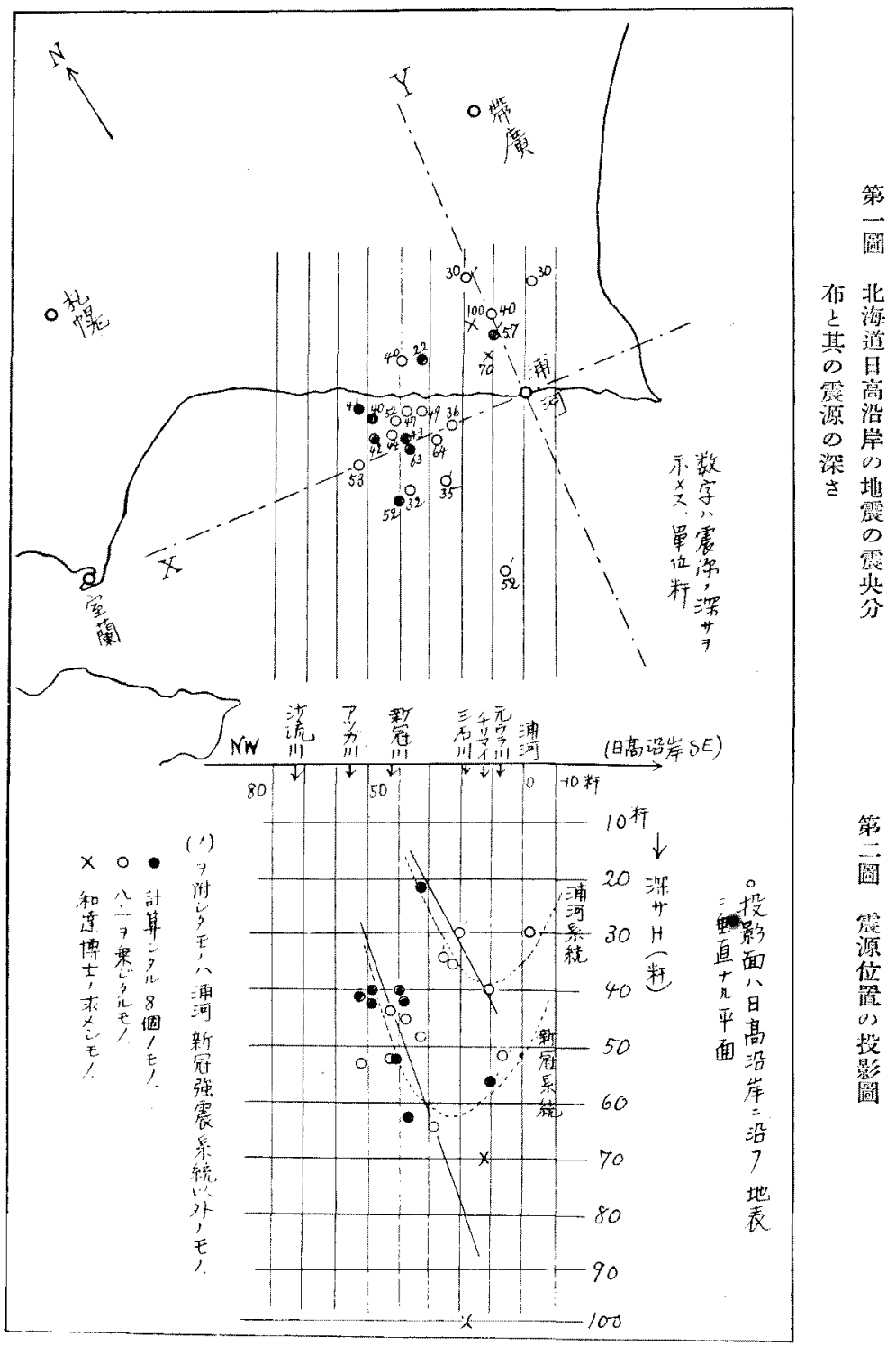




\section{3. 霥源位置の分布狀態}

震央位置の分布は第一圖に示め与が别くであ

る. 㨽中の震央位置の傍には震源の深さを數字

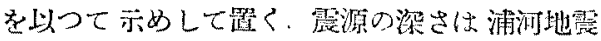
䒺統のものにては 20 40 料, 又新冠川此震系続

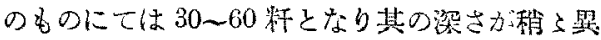
ろ.份內陸地方には別系続のむのとしてずつと深 い震源を有するるのが二三るる。

震源位置の分布仙，

日高沿崖に沿今地表面

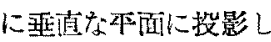
て見ると，其處に若干 の規則が見られる樣で ある、第二圖は其北を

\begin{tabular}{|c|c|}
\hline 媣さ(政) & 0 \\
\hline$K$ & $5-6$ \\
\hline$\tau$ (秒) & 0 \\
\hline 國富氏によるて & 0 \\
\hline \multicolumn{2}{|c|}{ 沿ひ 浦河より喃れるに } \\
\hline \multirow{2}{*}{\multicolumn{2}{|c|}{ 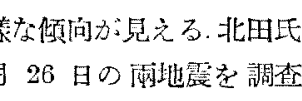 }} \\
\hline & \\
\hline \multirow{2}{*}{ 湶が日高沿岸に龊して直 } & \\
\hline & \\
\hline
\end{tabular}
端付沂にある樣になつて属る。

\section{4. 北海道浦河附近つ震波傅播の係數}

以上の調查に於いて，Kの梿を見るに深さと
共に㙛加して居ることが看取出來る、從つて震央 に於、て觀测される $(P-S)$ の值が色々の深さの

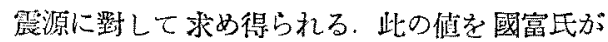

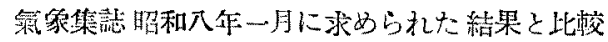

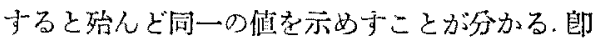

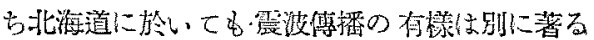
しい變化がないことが云は礼る、符二表に其等を 示声.

第 二 表

\begin{tabular}{|c|c|c|c|c|c|c|c|c|}
\hline $10 \quad 20$ & 30 & 40 & 50 & 60 & 70 & 80 & 90 & 100 \\
\hline 369 & $7 \cdot 5$ & 8.0 & 84 & $8 \cdot 8$ & $9 \cdot 1$ & 94 & $9 \cdot 7$ & 99 \\
\hline 28 & $4 \cdot 0$ & 50 & 60 & 69 & $7 \cdot 3$ & 87 & 94 & $10^{\circ} 1$ \\
\hline 3.7 & 3.8 & 4.9 & $5 \cdot 8$ & 677 & $7 \cdot 5$ & 85 & 93 & 10 \\
\hline
\end{tabular}

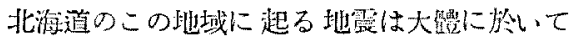
震源の樑さが 40 籸位であるから, 通常は $K$ の 值として 80 位を朋るて居ればよいと云ふこと になる.

(終)

（附記）以上は野村氏の調查の概要を抄銘し たものである.（和造）

\section{潮岬及筑波山の北東風と東京の降雨との關係比ついて}

村 䅋等 夫

On the Dependency of Rainfall in Tôkyô on the

NE Wind at Siomisaki and Tukuba.

By M. Murase.

潮䖬で北東風が吹くとその後東京で雨になり 易いといふ枒は(1)大地氏の閏查で明かでする。

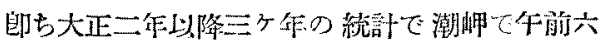
呩に北東風为粎き气の日の午後六時以後の二十

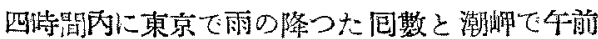
六時に北東風が吹いた包數の此は 0.65 である。

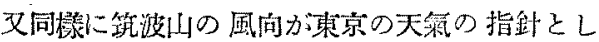
て有力であると云はれて居る。そこで啳六時の 潮岬，筑波の 北東風之椠日二十四時問內の 東京
の雨との閵係を大正十二年以降昭和七年迄の十 ヶ年の材料につき倜べた。

今東京て雨のるつた日数を $N$ ，全日藪を $N$ ， $\frac{N_{r}}{N}=n, N-N_{r}=N_{J}$ とすると $n=0.4744, \quad N_{r}=1173$

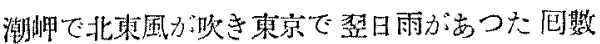

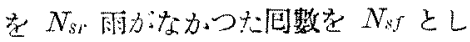

$$
x=\frac{N_{s r}}{N_{s i}+N_{s f}}
$$

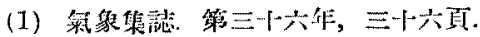

